\title{
A New Method for Isolating the Nonidentical Protein Subunits of Human Plasma $\alpha$-Lipoprotein
}

\author{
Daniel Rudman, Luis A. Garcia, and Carolyn H. Howard \\ From the Departments of Medicine and Biochemistry, Emory University School \\ of Medicine, Atlanta, Georgia 30322
}

A B S T R A C T Human plasma alpha lipoprotein ( $\alpha$ LP) was totally delipidated by gel filtration on Sephadex LH-20 in a medium of 2 butanol:acetic acid: $\mathrm{H}_{2} \mathrm{O}$, $4: 1: 5$. The resulting alpha protein $(\alpha \mathrm{P})$ exhibited two major bands, labeled $\mathrm{C}$ and $\mathrm{D}$, on acrylamide-gel electrophoresis in $5.0 \mathrm{M}$ urea at $\mathrm{pH} 8.8$ or 4.0 . Minor bands labeled $\mathrm{A}$ and $\mathrm{B}$, also present, were shown to be aggregates of $\mathrm{C}$ which form when the latter is lyophilized. The $\mathrm{C}$ and $\mathrm{D}$ components were isolated in pure form from $\alpha \mathrm{P}$ (prepared by LH-20 chromatography of $\alpha \mathrm{LP}$ ) by gel filtration of this protein on Sephadex G-200 in a medium of $1.0 \mathrm{~N}$ acetic acid: the $\mathrm{C}$ component emerged with a distribution coefficient $\left(K_{d}\right)$ of 0.4 , and the $D$ component with a coefficient of 0.7 . From each $100 \mathrm{mg}$ of $\alpha \mathrm{P}, 68 \mathrm{mg}$ of $\mathrm{C}$ and $22 \mathrm{mg}$ of $\mathrm{D}$ were isolated. $3 \mathrm{mg}$ of a minor fraction with $K_{d} 0.1$, containing $A$ and $B$ components as well as $C$, were also obtained. $D$ but not $C$ reacts with rabbit antiserum to human $\alpha \mathrm{LP} . \mathrm{C}$ and $\mathrm{D}$ differ substantially in content of arginine, histidine, $\frac{1}{2}$-cystine, isoleucine, and tryptophan.

\section{INTRODUCTION}

The protein moiety of human plasma $\alpha$-lipoprotein ( $\alpha \mathrm{LP}$ ) (d 1.063-1.21), which will be termed $\alpha \mathrm{P}$, is currently under study in several laboratories. The lipoprotein has been delipidated by treating the aqueous suspension with ethanol-diethyl ether (1) or with ethanol-acetone (2) or by lyophilizing the lipoprotein and then removing the lipid by ethanol-acetone extraction (3). The resulting $\mathrm{H}_{2} \mathrm{O}$-soluble preparations of $\alpha \mathrm{P}$ exhibit on ultracentrifugation in aqueous buffers two peaks, with $s_{20, \infty}$ values of 2 and 4-10 depending on $\mathrm{pH}$ (4) ; but they sediment as a single homogenous peak in $0.05 \mathrm{M}$ sodium dodecyl sulfate with molecular weight estimated as 23,710 by Scanu (4) and as 31,000 by Shore and Shore (5). These preparations, furthermore,

Received for publication 4 June 1969 and in revised form 10 August 1969. move as a single band in zone elctrophoresis in paper (6), agar gel (4), or cellulose acetate (3). Therefore, until recently it was thought that $\alpha \mathrm{P}$ consisted of a single peptide subunit, mol wt $23,000-31,000$, with a marked tendency towards aggregation.

Recently Shore and Shore (7) reported the presence of both glutamine and threonine as $\mathrm{C}$-terminal residues in $\alpha \mathrm{P}$. Furthermore, they observed that $\alpha \mathrm{P}$ was resolved into two major components by acrylamide-gel electrophoresis in $8.0 \mathrm{M}$ urea at $\mathrm{pH}$ 8.8. When $\alpha \mathrm{P}$ was chromatographed on a column of DEAE-cellulose in $\mathrm{pH}$ 8.0 Tris buffer containing $8.0 \mathrm{~m}$ urea, two minor and three major fractions were obtained. The first of the major chromatographic fractions represented in apparently pure form the more rapidly moving of the two components seen on disc electrophoresis. The next two major fractions obtained by chromatography appeared to contain both electrophoretic components with the slower moving one predominating. By rechromatography of the second major fraction on DEAE-cellulose in $8 \mathrm{M}$ urea, the slow electrophoretic component could also be isolated in pure form (8). Glutamine proved to be the $\mathrm{C}$-terminal residue of the rapid component (termed R-gln), and threonine that of the slow component ( $R-t h r$ ). R-gln and R-thr were found to differ substantially in amino acid composition. Shore and Shore concluded that $\alpha \mathrm{P}$ is a mixture of two non-identical peptides, and calculated from the yields of C-terminal glutamine and threonine per gram of $\alpha \mathrm{P}$, that each peptide has a molecular weight of about $15,000(7,8)$.

In this laboratory, evidence of a different type for the presence of two nonidentical subunits in $\alpha \mathrm{P}$ was also recently obtained (3). $\alpha \mathrm{P}$ was prepared by extracting the lyophilized $\alpha \mathrm{LP}$ with ethanol-acetone, dissolving the residual protein in $1.0 \mathrm{~N}$ acetic acid, and relyophilizing. This material was resolved by gel filtration on Sephadex G-200 in $1.0 \mathrm{~N}$ acetic acid into three fractions with distribution coefficient $\left(\mathrm{K}_{\mathrm{d}}\right)$ values $0.12,0.49$, and 0.64 The amino acid composition and tryptic fingerprints of 
TABLE I

Amino Acid Composition of $\alpha P$,

\begin{tabular}{|c|c|c|c|c|c|}
\hline \multirow[b]{2}{*}{ Amino acid } & \multicolumn{3}{|c|}{$\alpha \mathrm{P}$} & \multicolumn{2}{|c|}{ Fraction I } \\
\hline & $\begin{array}{c}\text { Prepa- } \\
\text { ration } 1\end{array}$ & $\begin{array}{l}\text { Prepa- } \\
\text { ration } 2\end{array}$ & $\begin{array}{l}\text { Prepa- } \\
\text { ration } 3\end{array}$ & $\begin{array}{l}\text { Prepa- } \\
\text { ration } 1\end{array}$ & $\begin{array}{l}\text { Prepa- } \\
\text { ration } 3\end{array}$ \\
\hline Lysine§ & 94.0 & 80.5 & 90.1 & 91.9 & 93.1 \\
\hline Histidinef & 16.2 & 14.7 & 15.3 & 17.1 & 15.6 \\
\hline Arginine & 46.3 & 47.2 & 48.5 & 59.5 & 60.5 \\
\hline Aspartic acid $\ddagger$ & 76.7 & 81.3 & 79.5 & 82.9 & 84.7 \\
\hline Threonine\| & 48.2 & 46.9 & 50.1 & 39.0 & 38.3 \\
\hline Serine $\|$ & 62.3 & 60.7 & 65.5 & 60.4 & 62.9 \\
\hline Glutamic acid $\ddagger$ & 191.2 & 206.3 & 189.3 & 199.5 & 200.1 \\
\hline Proline & 41.7 & 40.2 & 45.3 & 40.7 & 36.8 \\
\hline Glycinef & 47.7 & 44.5 & 44.1 & 41.5 & 43.5 \\
\hline Alanine & 74.1 & 73.0 & 76.2 & 75.1 & 74.0 \\
\hline 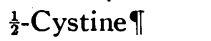 & 4.3 & 5.4 & 5.2 & 0 & 0 \\
\hline Valine§ & 57.8 & 60.6 & 60.4 & 54.8 & 55.6 \\
\hline Methionine $ף$ & 12.0 & 13.3 & 13.1 & 14.2 & 14.7 \\
\hline Isoleucine§ & 7.1 & 7.7 & 7.3 & 0 & 0 \\
\hline Leucine $\ddagger$ & 135.3 & 133.4 & 131.7 & 146.5 & 151.3 \\
\hline Tyrosine $\|$ & 29.6 & 27.1 & 26.9 & 23.8 & 22.4 \\
\hline Phenylalanine & 32.6 & 33.4 & 34.1 & 23.8 & 26.1 \\
\hline Tryptophan** & 23.1 & 22.4 & 22.0 & 30.4 & 28.4 \\
\hline
\end{tabular}

Values represent moles of each residue/1000 moles of amino acids. Preparations labeled 1 were derived from $\alpha$ LP of subject L.A.G.; those labeled 2, from subject A.D.R.; those labeled 3, from subject S.A.

* From Shore and Shore (ref 8).

‡ Values obtained by averaging results of $24-\mathrm{hr}, 48-\mathrm{hr}$, and 72 -hr hydrolyzates.

$\$$ Average of two highest values among $24-, 48-$, and 72-hr hydrolyzates.

$\|$ Values calculated by extrapolation to zero time.

I Determined after oxidation with performic acid.

** Determined colorimetrically.

the three fractions were different, and only the third ( $\left.K_{d} 0.64\right)$ reacted with antiserum to $\alpha \mathrm{LP}$. It was concluded that $\alpha \mathrm{P}$ contained two different subunits, that one of these subunits was the principal component of the third fraction, and that the other subunit (which appeared to have a greater tendency to aggregate in $1.0 \mathrm{~N}$ acetic acid) was the principal component of the first two fractions.

Thus it appears established that $\alpha \mathrm{P}$ is a mixture of two nonidentical peptides, but methods for totally separating the peptides and isolating each in pure form are still inadequate, in part due to the tendency towards aggregation of the peptides after the lipid has been removed. We have therefore investigated different methods of delipidating $\alpha \mathrm{LP}$ and separating the two major subunits. Cellular lipoproteins have been successfully delipidated by chromatography in organic solvents on the recently introduced Sephadex $\mathrm{LH}-20$, an alkylated derivative of Sephadex G-25 (9). We have now found that human plasma $\alpha$ LP can be totally delipidated by the same technique. The resulting $\alpha \mathrm{P}$ exhibits two major components on disc electrophoresis in $5.0 \mathrm{~m}$ urea, $\mathrm{pH}$ 8.9 buffer. Furthermore, $\alpha \mathrm{P}$ prepared in this manner is resolved by gel filtration on Sephadex G-200 into two major fractions, one containing only the slow electrophoretic component, and the other containing only the fast component. The two components, now readily available in pure form, have been shown to differ in quantitative amino acid composition, and in reactivity with antiserum to $\alpha \mathrm{LP}$. Their electrophoretic mobilities and amino acid compositions suggest that they correspond to R-gln and R-thr of Shore and Shore.

\section{METHODS}

$\alpha \mathrm{P}$ was prepared from the plasma of fasting normal male subjects, $20-40$ yr old, as described previously (3). The purity of each preparation was documented, as in the previous study, by its movement as a single band on cellulose acetate membranes at $\mathrm{pH} 8.6$ and $\mathrm{pH} 3.9$, by formation of a single line of precipitation with rabbit antiserum to human $\alpha \mathrm{LP}$ in Ouchterlony immunodiffusion, and by failure to react in immunodiffusion with antisera to human serum albumin, $\beta$-lipoprotein, transferrin, fibrinogen, $\gamma$-globulin, or $\alpha_{2}$-haptoglobin. 
Fraction I, Fraction II, and Fraction III

\begin{tabular}{cccrrrrrr}
\hline & Fraction II & & \multicolumn{3}{c}{ Fraction III } \\
\cline { 5 - 7 } $\begin{array}{c}\text { Prepa- } \\
\text { ration 1 }\end{array}$ & $\begin{array}{c}\text { Prepa- } \\
\text { ration 2 }\end{array}$ & $\begin{array}{c}\text { Prepa- } \\
\text { ration 3 }\end{array}$ & $\begin{array}{c}\text { Prepa- } \\
\text { ration 1 }\end{array}$ & $\begin{array}{c}\text { Prepa- } \\
\text { ration 2 }\end{array}$ & $\begin{array}{c}\text { Prepa- } \\
\text { ration 3 }\end{array}$ & R-gln* & R-thr* \\
\hline 90.1 & 99.1 & 95.6 & 118.1 & 129.7 & 120.5 & 115.0 & 77.7 \\
17.1 & 16.0 & 17.5 & 3.7 & 3.6 & 3.8 & 0 & 22.6 \\
57.0 & 61.0 & 62.8 & 9.4 & 9.0 & 9.8 & 0 & 67.6 \\
88.2 & 85.2 & 83.5 & 55.1 & 55.3 & 52.0 & 40.6 & 98.0 \\
40.5 & 39.0 & 37.9 & 69.7 & 70.0 & 71.3 & 81.9 & 38.0 \\
59.4 & 60.6 & 62.6 & 72.5 & 70.0 & 72.4 & 82.3 & 62.5 \\
198.6 & 187.2 & 190.0 & 203.6 & 193.0 & 191.8 & 197.6 & 181.0 \\
38.1 & 40.6 & 41.7 & 50.4 & 50.5 & 53.4 & 52.3 & 36.9 \\
43.1 & 44.5 & 45.5 & 45.5 & 44.7 & 46.5 & 42.5 & 44.3 \\
77.8 & 69.2 & 71.5 & 66.3 & 69.0 & 70.5 & 68.1 & 75.8 \\
0 & 0 & 0 & 13.3 & 12.8 & 12.1 & 15.0 & 0 \\
49.8 & 57.1 & 55.8 & 73.1 & 74.8 & 70.7 & 76.8 & 51.3 \\
13.1 & 14.4 & 15.0 & 12.7 & 13.0 & 14.0 & 14.8 & 15.0 \\
0 & 0 & 0 & 20.0 & 17.7 & 19.3 & 15.0 & 0 \\
145.9 & 150.3 & 150.9 & 98.8 & 95.6 & 99.9 & 103.2 & 148.1 \\
24.9 & 22.0 & 22.6 & 42.6 & 38.9 & 40.6 & 45.2 & 28.4 \\
25.7 & 23.3 & 26.1 & 48.8 & 49.0 & 50.1 & 49.9 & 22.9 \\
30.0 & 30.4 & 29.5 & 0 & 0 & 0 & 0 & 30.0 \\
\hline & & & & & & & &
\end{tabular}

Two types of column chromatography were employed, both at room temperature. (a) $\alpha \mathrm{LP}$ was chromatographed on Sephadex LH-20 (Pharmacia). The gel particles were swollen and washed, with removal of fines, in 2 butanol: acetic acid: water, $4: 1: 5$; a slurry of the concentrated gel was packed by gravity in a $3 \times 100 \mathrm{~cm}$ column. A sample of aLP containing $40-70 \mathrm{mg}$ of lipoprotein-protein was dissolved, as described in the experimental section, in $10 \mathrm{ml}$ of the 2 butanol:acetic acid: water solvent system and introduced into the column; the column was eluted with the same solvent, at a flow rate of $40 \mathrm{ml} / \mathrm{hr}$. $10-\mathrm{ml}$ fractions were collected, $0.5-\mathrm{ml}$ aliquots of each were dried at $80^{\circ} \mathrm{C}$ in vacuo, hydrolyzed in $2.5 \mathrm{~N} \mathrm{NaOH}$ at $90^{\circ} \mathrm{C}$, and analyzed with the colorimetric ninhydrin reagent (10). To analyze each fraction of the column for lipid content, $0.5-\mathrm{ml}$ aliquots were dried at $80^{\circ} \mathrm{C}$ in vacuo and analyzed by the carboxyl ester method (11). (b) Preparations of $\alpha \mathrm{P}$ (20-70 mg) dissolved in 4-10 ml $1.0 \mathrm{~N}$ acetic acid were chromatographed on a $2 \times 200 \mathrm{~cm}$ column of Sephadex G-200 as previously described (3). A $0.2-0.5 \mathrm{ml}$ aliquot of each $10 \mathrm{ml}$ fraction was analyzed by the colorimetric ninhydrin reagent after alkaline hydrolysis.

Electrophoresis of $\alpha \mathrm{P}$ and fractions of $\alpha \mathrm{P}$ in $7.5 \%$ acrylamide gel was done in two systems: $\mathrm{pH} 8.9,5.0 \mathrm{M}$ urea; and $\mathrm{pH} 4.0,5.0 \mathrm{~m}$ urea. The techniques of Ornstein and Davis (12) were used throughout, except that urea was added to the gel to a final concentration of 5 moles/liter.
Immunodiffusion of $\alpha \mathrm{LP}, \alpha \mathrm{P}$ and fractions of $\alpha \mathrm{P}$ was done as described previously (3). Antisera were purchased from Behringwerke and Hyland Laboratories, and their specificity was verified as in the previous study.

Phospholipid, total cholesterol, and carboxyl ester content of both ethanol-acetone $(1: 1)$ and chloroform-methanol (2:1) extracts of lyophilized $\alpha \mathrm{P}$ preparations were determined according to Fiske and Subbarow (13), Abell, Levy, Brodie, and Kendall (14), and Rosenthal, Pfluke, and Callerami (11), respectively.

For measurement of the amino acid composition of $\alpha \mathrm{P}$ and fractions thereof, duplicate samples of 1-2 $\mathrm{mg}$ of protein were hydrolyzed in $6.0 \mathrm{~N} \mathrm{HCl}$ at $110^{\circ} \mathrm{C}$ for 24,48 , or $72 \mathrm{hr}$ in sealed evacuated tubes. The hydrolysates were taken to dryness on a rotary evaporator at $40^{\circ} \mathrm{C}$, and analyzed on a Beckman-Spinco $120 \mathrm{C}$ instrument with the "4 $\mathrm{hr}$ protein hydrolyzate system" (15). Except for $\frac{1}{2}$-cystine, methionine, and tryptophan, values for each residue were calculated by extrapolation of 24,48 , and $72 \mathrm{hr}$ hydrolysate data to zero time, or by averaging the two highest among the 24-, 48-, and 72-hr values as indicated in Table I. $\frac{1}{2}$-cystine and methionine were determined as cysteic acid and methionine sulfone on duplicate $24 \mathrm{hr} 6.0$ N $\mathrm{HCl}$ hydrolysates of performic acid-oxidized protein; a $94 \%$ recovery of cysteic acid was assumed (16). Calculation of the protein's content of $\frac{1}{2}$-cystine and methionine was based on the ratio of cysteic acid or of methionine sulfone 
to leucine recovered in the same analysis of oxidized protein, and on the known content of leucine in the unoxidized protein. Tryptophan, destroyed by acid hydrolysis, was determined by the method of Spies and Chambers (17). The composition of the protein was expressed as moles of each residue per 1000 moles of amino acid.

\section{RESULTS}

Delipidation of $\alpha L P$ on $L H-20$ column. From $270 \mathrm{ml}$ of normal human plasma, we obtained $80-100 \mathrm{ml}$ of $\alpha \mathrm{LP}$ solution. After documentation of purity by electrophoresis on cellulose acetate and by immunodiffusion against antisera to various human plasma proteins, a 25 $\mathrm{ml}$ batch of this solution was freed of salt by dialyzing against 12.0 liters $\mathrm{H}_{2} \mathrm{O}$ overnight and then concentrated 4 to 5 -fold by dialysis against $20 \%$ polyvinylpyrrolidone (grade 40 ). To $5 \mathrm{ml}$ of this turbid concentrate was added dropwise, with stirring, a mixture of $1 \mathrm{ml}$ acetic acid with $4 \mathrm{ml}$ sec-butanol. The $\alpha \mathrm{LP}$ solution became transparent during this addition. This solution (containing about $40-70 \mathrm{mg}$ lipoprotein-protein) was then subjected to gel filtration on $\mathrm{LH}-20$, with the result shown in Fig. 1. $90 \%$ of the protein of $\alpha \mathrm{LP}$ was recovered in tubes $23-27$ (cumulative volume $230-270 \mathrm{ml}$ ) unaccompanied by any detectable lipid; all the lipid was recovered in tubes $33-42$. Tubes $23-27$ were pooled,

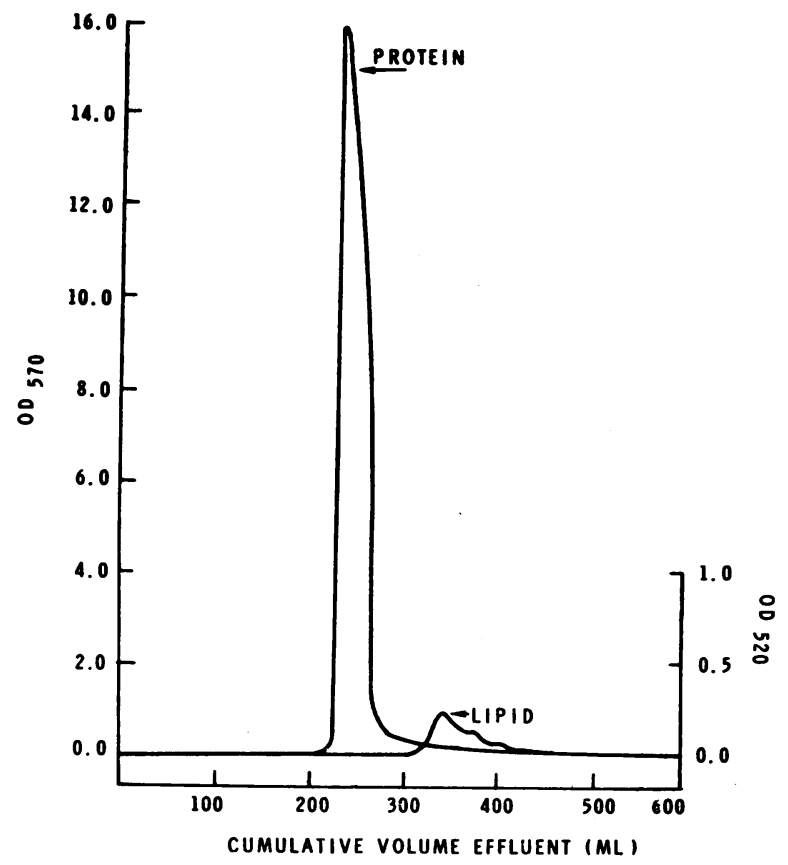

FIgURE 1 Gel filtration of $\alpha \mathrm{LP}$ containing $50 \mathrm{mg}$ protein on a $3 \times 100 \mathrm{~cm}$ column of Sephadex LH-20 in a medium of 2 butanol:acetic acid: $\mathrm{H}_{2} \mathrm{O}$ 4:1:5 (v/v/v). Left-hand ordinate scale represents optical density of colorimetric ninhydrin analysis; right-hand ordinate shows optical density of carboxyl ester analysis.

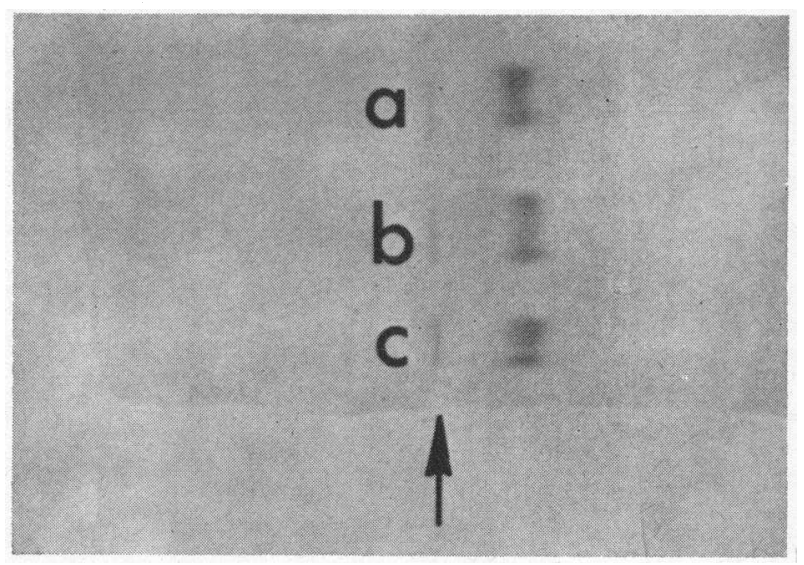

FIGURE 2 Electropherogram on cellulose acetate in barbital buffer $(\mathrm{pH} 8.6)$ containing $2.0 \mathrm{M}$ urea of $(a)$ unlyophilized $\alpha \mathrm{P}(\mathrm{LH}-20),(b)$ lyophilized $\alpha \mathrm{P}(\mathrm{LH}-20)$, and (c) $\alpha \mathrm{P}$ $(\mathrm{E} / \mathrm{A})$. Arrow indicates line of sample application.

and concentrated from a volume of $50 \mathrm{ml}$ to $8 \mathrm{ml}$ by a stream of $\mathrm{N}_{2}$ at $40^{\circ} \mathrm{C}$. This concentrated solution contained about 7-11 $\mathrm{mg}$ protein $/ \mathrm{ml}$. In order to characterize the protein in the solution and to determine the optimal means of recovering the protein from it, the following experiments were done.

Characterization of $\alpha P$ prepared by $L H-20$. Preparatory to immunodiffusion or electrophoresis in various systems, $1 \mathrm{ml}$ aliquots of this concentrated solution were dialyzed against 1.0 liter of each of these solutions : 0.05 M $\mathrm{Na}_{2} \mathrm{HPO}_{4}$ for immunodiffusion and for electrophoresis at $\mathrm{pH} 8.6-8.8$ on cellulose acetate or in acrylamide gel; $1.0 \mathrm{~N}$ acetic acid for electrophoresis at $\mathrm{pH} 3.9$ on cellulose acetate or at $\mathrm{pH} 4.0$ in acrylamide gel. These preparations will be referred to as "unlyophilized $\alpha \mathrm{P}$ (LH-20)." A $5 \mathrm{ml}$ aliquot was dialyzed against 1.0 liter of $1.0 \mathrm{~N}$ acetic acid and then lyophilized to yield $30-50$ $\mathrm{mg}$ of white fluffy powder readily soluble in aqueous buffers from $\mathrm{pH} 3$ to $\mathrm{pH} 11$. Samples of this material (termed "lyophilized $\alpha \mathrm{P}$ [LH-20]"), dissolved in the appropriate buffer, were compared in some tests with unlyophilized $\alpha \mathrm{P}$ (LH-20), in order to determine the possible effect of lyophilization on the electrophoretic and immunodiffusion patterns; the lyophilized preparation was also used in determining the lipid content and quantitative amino acid composition of $\alpha \mathrm{P}$ prepared by the LH-20 technique. Finally, in some experiments, from the same batch of $\alpha \mathrm{LP}$ used to prepare $\alpha \mathrm{P}$ (LH-20), a sample of $\alpha \mathrm{P}$ (termed $\alpha \mathrm{P}[\mathrm{E} / \mathrm{A}]$ ) was prepared by the previously described method (3) of lyophilizing $\alpha \mathrm{LP}$, extracting the lipid with ethanol-acetone, dissolving the residual $\alpha \mathrm{P}$ in $1.0 \mathrm{~N}$ acetic acid, and relyophilizing. This was done in order to compare the properties of $\alpha \mathrm{P}$ prepared by two different techniques of delipidation. In addition, several preparations of fractions I, II, and III 

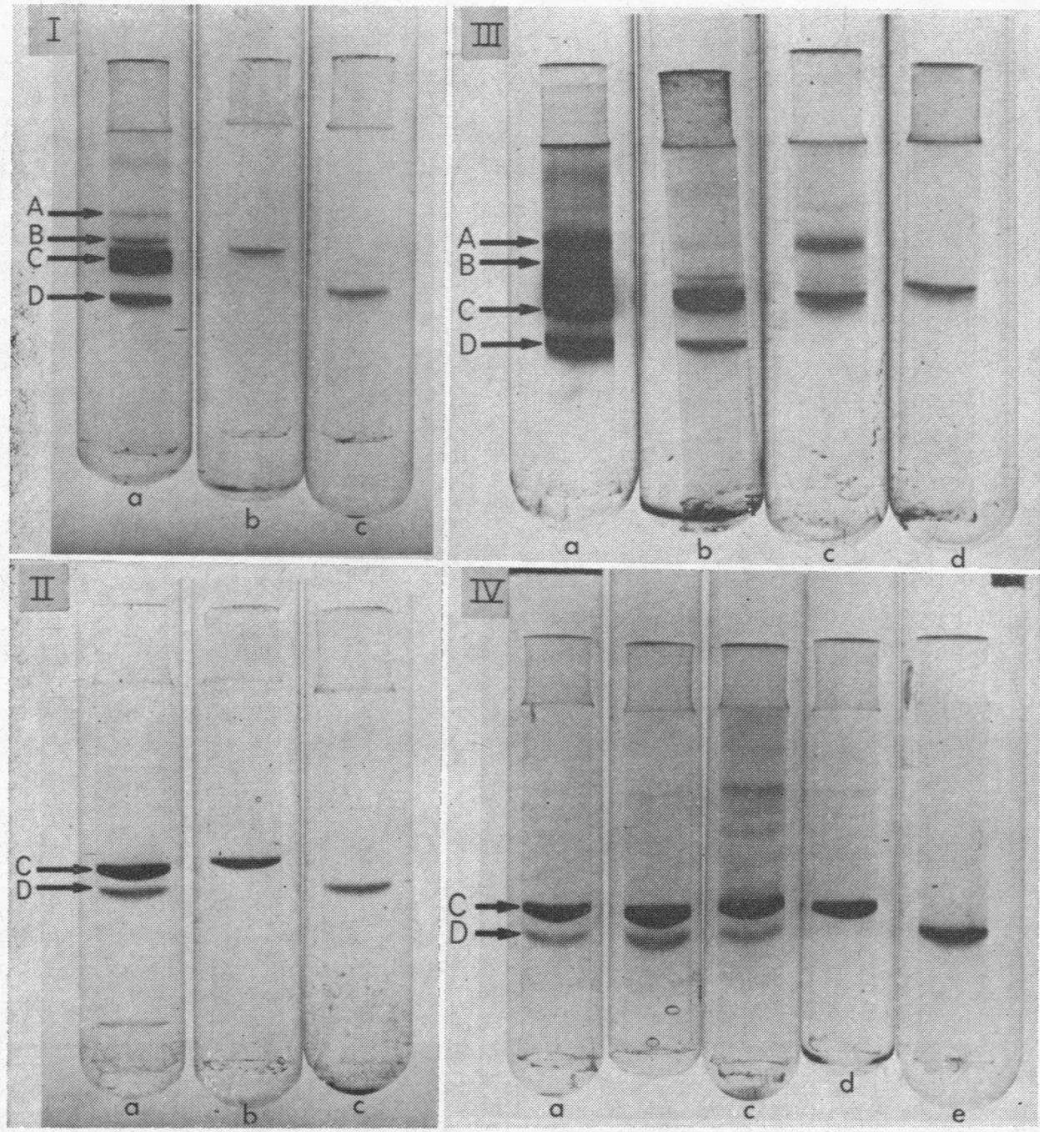

Figure 3 Panel I. Disc electrophoresis in $5.0 \mathrm{~m}$ urea, $\mathrm{pH} 8.8$ buffer for $1 \mathrm{hr}$, (a) unlyophilized $\alpha \mathrm{P}$ (LH-20); (b) unlyophilized fraction II; (c) unlyophilized fraction III. Panel II. Disc electrophoresis in $5.0 \mathrm{~m}$ urea, $\mathrm{pH} 4$ buffer for $1 \mathrm{hr},(a)$ unlyophilized $\alpha \mathrm{P}(\mathrm{LH}-20)$; $(b)$ unlyophilized fraction II ; $(c)$ unlyophilized fraction III. Panel III. Disc electrophoresis in $5.0 \mathrm{M}$ urea, $\mathrm{pH} 8.8$ buffer for $1.5 \mathrm{hr},(a)$ lyophilized $\alpha \mathrm{P}$ (LH-20); (b) unlyophilized $\alpha \mathrm{P}(\mathrm{LH}-20)$; (c) unlyophilized fraction I; (d) unlyophilized fraction II. Panel IV. Disc electrophoresis in $5.0 \mathrm{M}$ urea, $\mathrm{pH} 4$ buffer for $1.5 \mathrm{hr}$, (a) unlyophilized $\alpha \mathrm{P}$ (LH-20); (b) lyophilized $\alpha \mathrm{P}(\mathrm{LH}-20) ;(c) \alpha \mathrm{P}$ (E/A); (d) lyophilized fraction II; (e) lyophilized fraction III.

derived from $\alpha \mathrm{P}$ (E/A) in our previous study (3) by gel filtration on Sephadex G-200 were reexamined in the present investigation by acrylamide-gel electrophoresis in $5.0 \mathrm{M}$ urea, $\mathrm{pH} 8.9$ buffer.

$\alpha \mathrm{P}$ prepared by the LH- 20 technique contained no detectable phospholipid, cholesterol, or triglyceride (less than $0.01 \mathrm{mg}$ of each lipid species per $\mathrm{mg}$ of $\alpha \mathrm{P}$ ). On cellulose acetate membranes at $\mathrm{pH} 8.6$ or $\mathrm{pH} 3.9$, unlyophilized $\alpha \mathrm{P}$ (LH-20), lyophilized $\alpha \mathrm{P}$ (LH-20), $\alpha \mathrm{P}$ (E/A), and $\alpha \mathrm{LP}$ itself all moved as single bands with identical mobility (Fig. 2). All four preparations gave a single line of precipitation on double diffusion against anti- $\alpha \mathrm{LP}$; the three preparations of $\alpha \mathrm{P}$ showed a reaction of identity, while spur formation was present between this line of reaction and the line of reaction be- tween $\alpha \mathrm{LP}$ and its antiserum. The three types of $\alpha \mathrm{P}$ showed similar but not identical patterns on acrylamidegel electrophoresis (Fig. 3). At $\mathrm{pH} 8.9$, unlyophilized $\alpha \mathrm{P}$ (LH-20) exhibited two major bands, labeled C and D, D being the more rapid. Two fainter bands, $\mathrm{A}$ and $\mathrm{B}$, followed $\mathrm{C}$, and occasionally a faint component slower than A could be seen (Fig. 3, I- $a,{ }^{1} 3$, III- $b$ ). The effect of lyophilizing $\alpha \mathrm{P}$ (LH-20) was to increase the prominence of the A and B bands (Fig. 3, III- $a$ ), $\alpha \mathrm{P}$ (E/A) resembled lyophilized $\alpha \mathrm{P}(\mathrm{LH}-20)$ but additional bands slower than A were more prominent. At $\mathrm{pH} 4$, unlyophilized $\alpha \mathrm{P}$ (LH-20) showed only two visible bands, the slower being labeled $\mathrm{C}$ and the faster $\mathrm{D}$ because subsequent experiments identified them as corresponding to

\footnotetext{
${ }^{1}$ Electropherogram a in panel I of Fig. 3.
} 

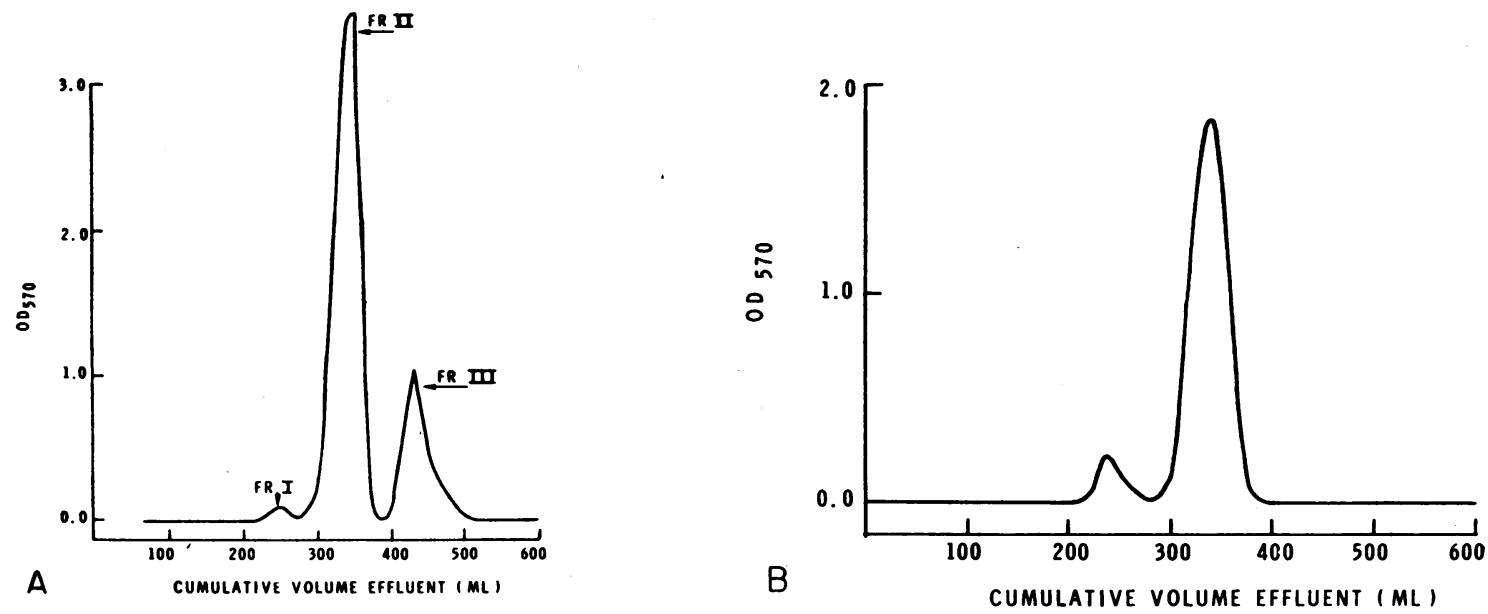

FIgUre 4 A. Gel filtration of $40 \mathrm{mg}$ unlyophilized $\alpha \mathrm{P}$ (LH-20) on $2 \times 200 \mathrm{~cm}$ column of Sephadex G-200 in $1.0 \mathrm{~N}$ acetic acid. Ordinate shows ninhydrin value $\left(\mathrm{OD}_{570}\right)$ per $\mathrm{ml}$ of hydrolyzed effluent. Abscissa shows cumulative volume of effluent, collected in 10-ml fractions. B. Gel filtration under same conditions of $20 \mathrm{mg}$ lyophilized fraction II.

the $\mathrm{C}$ and $\mathrm{D}$ bands in the alkaline electropherograms. Lyophilized $\alpha \mathrm{P}(\mathrm{LH}-20)$ showed a series of faint bands preceding $\mathrm{C}$ (Fig. 3, IV-a); this series was more prominent in $\alpha \mathrm{P}$ (E/A) (Fig. 3, IV-c).

Separation of $\alpha P(L H-20)$ into three fractions by gel filtration on $G-200.40 \mathrm{mg}$ of unlyophilized $\alpha \mathrm{P}$ (LH-20) in $4 \mathrm{ml} 1.0 \mathrm{~N}$ acetic acid was placed on the Sephadex G-200 column and eluted with the same solvent. Ninhydrin analysis of the effluent (Fig. $4 \mathrm{~A}$ ) revealed three peaks : a minor fraction $I, K_{d}$ value 0.1 ; and major fractions II and III with $K_{d}$ values 0.4 and 0.7 . Each peak was pooled and concentrated 10 -fold by evaporation under nitrogen at $40^{\circ} \mathrm{C} .1 \mathrm{ml}$ aliquots of these three concentrates were dialyzed against $5.0 \mathrm{~m}$ urea buffer of $\mathrm{pH}$ 8.8 and 4.0, preparatory to acrylamide-gel electrophoresis. The electropherograms at both $\mathrm{pH}$ 's showed that fraction II contained only band C, and that fraction III contained only band D (Fig. 3, I- $b$ and $c$, and 3, II- $b$ and $c)$. Fraction $I$ consisted of a mixture of $C$ with varying amounts of A and B (Fig. 3, III-c). The remainder of these three fractions were then lyophilized. Yields from $100 \mathrm{mg} \alpha \mathrm{P}$ averaged $2 \mathrm{mg}$ fraction I, $68 \mathrm{mg}$ fraction II, and $22 \mathrm{mg}$ fraction III. Lyophilization led to the appearance of a series of bands (including $\mathrm{A}$ and $\mathrm{B}$ ) slower and fainter than band $\mathrm{C}$ in both the $\mathrm{pH} 8.8$ and $\mathrm{pH} 4$ disc electropherograms of fraction II; it did not alter the appearance of fraction III (Fig. 3, IV- $d$ and $e$ ). On immunodiffusion fraction III reacted with anti- $\alpha \mathrm{LP}$, showing a line of identity with lyophilized $\alpha \mathrm{P}$ (LH-20); fraction II was unreactive. ${ }^{2}$ When unlyophilized fraction

\footnotetext{
2 These observations were confirmed with preparations of fractions II and III from five different blood donors and with three different lots of rabbit antiserum to human $\alpha \mathrm{LP}$ : Behringwerke lots $927 / \mathrm{c} 67,1228 \mathrm{~b} / \mathrm{g} 67$, and $9713 / \mathrm{c} 67$.
}

II was passed through the G-200 column in $1.0 \mathrm{~N}$ acetic acid a second time, it emerged with unchanged $\mathrm{K}_{\mathrm{d}}$ of 0.4 ; but when lyophilized fraction II was passed through the G-200 column a second time, the elution profile revealed about $15 \%$ fraction I and $85 \%$ fraction II (Fig. $4 \mathrm{~B})$. Fractions II and III showed major differences in their content of the following amino acids: histidine, arginine, $\frac{1}{2}$-cystine, isoleucine, and tryptophan (Table I). Fractions I and II, on the other hand, did not differ significantly in amino acid composition.

We had previously (3) prepared $\alpha \mathrm{P}$ (E/A) by extraction of lyophilized $\alpha \mathrm{LP}$ and separated this $\alpha \mathrm{P}$ on G-200 into fractions I, II, and III with $\mathrm{K}_{\mathrm{d}}$ values of approximately $0.1,0.4$, and 0.6. For comparative purposes samples of these three earlier fractions were now reexamined in the present acrylamide-gel systems. Fraction III consisted of a doublet in the region of the $D$ band with one minor component slower than A. Fraction II consisted mainly of $\mathrm{C}$ band, with $\mathrm{A}$ and $\mathrm{B}$ visible; fraction I was a mixture of $\mathrm{C}, \mathrm{A}$ and several bands slower than A.

\section{DISCUSSION}

Gel filtration of $\alpha \mathrm{LP}$ in 2 butanol: acetic acid: $\mathrm{H}_{2} \mathrm{O}$ ( $4: 1: 5)$ appears to be an effective way of preparing totally $(>99 \%)$ delipidated $\alpha \mathrm{P}$. Unlyophilized $\alpha \mathrm{P}$ prepared by this method presents a gel electrophoretic pattern in $5.0 \mathrm{~m}$ urea, $\mathrm{pH} 8.8$ buffer of two major bands $\mathrm{C}$ and $\mathrm{D}$, with two minor slower bands $\mathrm{A}$ and $\mathrm{B}$. This is generally similar to that of the $\alpha \mathrm{P}$ of Shore and Shore (7), delipidated with ethanol-ether and examined in $8.0 \mathrm{M}$ urea at $\mathrm{pH}$ 8.8. Lyophilization of the present $\alpha \mathrm{P}$ preparation increases the prominence of bands migrating 
more slowly than $\mathrm{C}$ in both acid and alkaline electropherograms. On gel filtration of $\alpha \mathrm{P}$ (LH-20) on G-200 in $1.0 \mathrm{~N}$ acetic acid, these minor bands of slow mobility are recovered in the minor, highly aggregated fraction I. Lyophilization of fraction II containing only $\mathrm{C}$ band (but not of fraction III containing only $D$ band) leads to appearance of $\mathrm{A}$ and $\mathrm{B}$ by disc electrophoresis and fraction $I$ by gel filtration. Thus bands $A$ and $B$ appear to be aggregates of band $\mathrm{C}$. This is supported by the closely similar amino acid compositions of fractions I and II. Numerous slow bands, including $\mathrm{A}$ and $\mathrm{B}$, are also prominent in $\alpha \mathrm{P}$ which has been prepared by the previous method of extracting lyophilized $\alpha \mathrm{LP}$ and then lyophilizing the resulting lipid-free protein. This latter type of $\alpha \mathrm{P}$ also contains a more prominent high molecular weight component, $K_{d} 0.1$, by gel filtration on G-200, than does the present unlyophilized $\alpha \mathrm{P}$ (LH-20) (3). Thus it seems probable that exposure of $\alpha \mathrm{P}$ in the solid phase to ethanol-acetone, as well as lyophilization, leads to extensive aggregation of the "C component" of $\alpha \mathrm{P}$, leading to a more complicated pattern on analysis by gel filtration or by acrylamide-gel electrophoresis.

$\alpha \mathrm{P}$ (LH-20) thus contains two major components, $\mathrm{C}$ and $\mathrm{D}$, by acrylamide-gel electrophoresis. The $\mathrm{C}$ band is recovered in pure form as fraction II $\left(K_{d} 0.4\right)$ after gel filtration on G-200, and the D band as fraction III $\left(K_{d} 0.7\right)$. These two components differ in their amino acid composition, showing that $\mathrm{C}$ is not merely a more aggregrated form of the same protein present in $\mathrm{D}$. The absence of $\frac{1}{2}$-cystine and of isoleucine in C (fraction II), while they constitute about 13 and 19 moles/1000 residues in $D$ (fraction III), indicates that if $D$ is a single protein species it is not present to a detectable extent in C. Reaction of $\mathrm{D}$ but not of $\mathrm{C}$ with the antiserum to $\alpha \mathrm{LP}$ is additional evidence for the same conclusion. Conversely, the absence of tryptophan in D, and its presence in $\mathrm{C}$, show that if $\mathrm{C}$ is a single protein species, it is not present to a detectable extent in D. The simplest hypothesis consistent with all the data is that $\alpha \mathrm{P}$ is made up of two nonidentical subunits, corresponding to the $\mathrm{C}$ and $\mathrm{D}$ bands. The work of others $(4,5,7)$ indicates that these two nonidentical subunits have closely similar molecular weights, although estimates of this value have ranged from 15,000 to 31,000 . The separability of $\mathrm{C}$ and $\mathrm{D}$ components by gel filtration despite this similarity in molecular weight suggests that after delipidation $\mathrm{C}$ has either a greater tendency to aggregate with itself in $1.0 \mathrm{~N}$ acetic acid, or a larger radius, or both, than does $\mathrm{D}$.

The present information does not rule out the possibility that more than two subunits could be present. Thus, if the isoleucine-containing $K_{d} 0.6$ fraction III (band $D$ ) contained two peptides, one of which lacked isoleucine, then the absence of isoleucine in $K_{d} 0.4$ frac- tion II (band C) would no longer prove that fractions II and III do not have a subunit peptide in common. Conversely, if fraction II (band C) contained two proteins, one of which lacked tryptophan, then the absence of tryptophan in fraction III (band D) would not prove that $\mathrm{C}$ and $\mathrm{D}$ do not contain a subunit in common. For the present, however, there is no actual evidence for more than two components in $\alpha \mathrm{P}$ or for heterogeneity of components $\mathrm{C}$ and $\mathrm{D}$.

The $C$ and $D$ bands in the alkaline gel electropherogram of the present $\alpha \mathrm{P}$ resemble the two major components in Shores' $\alpha \mathrm{P}$, analyzed in a similar electrophoretic system (7). Presumably the present $C$ (fraction II) is identical to the Shores' slow component R-thr, while D (fraction III) is identical with their fast component (R-gln). This conclusion is supported by the general similarity in amino acid composition of fraction II and R-thr, and of fraction III and R-gln (Table I). Thus fraction II in comparison to fraction III contains a substantially greater proportion of histidine, arginine, leucine, and tryptophan, and a considerably lesser proportion of lysine, threonine, $\frac{1}{2}$-cystine, isoleucine, tyrosine, and phenylalanine. Similar relationships were reported by Shore and Shore (8) for R-thr compared to R-gln. Nevertheless the two sets of amino acid data do not agree completely. All three preparations of fraction III contain small but definite proportions of histidine and arginine, reported to be absent in R-gln. Lesser discrepancies concern lysine and aspartic acid in fraction II vs. R-thr, and aspartic acid, threonine, and serine in fraction III vs. R-gln. The explanation for these inconsistencies between the two sets of data is not presently apparent.

What is the relation of the present $\mathrm{C}$ and $\mathrm{D}$ components to fractions I, II and III of $\alpha \mathrm{P}$ described in our earlier report (3)? Acrylam:de-gel electrophoresis indicates that $\mathrm{D}$ is the major component in fraction III, and $\mathrm{C}$ the major component in fractions I and II but that some cross-contamination of the two nonidentical subunits was present in these earlier preparations. The cleaner separation of the two types of subunit by Sephadex G-200 in the present than in the earlier study may be related to the lesser proportion of highly aggregated material in $\alpha \mathrm{P}$ (LH-20) than in $\alpha \mathrm{P}$ (E/A).

The present technique has the advantage of a complete separation of $C$ and $D$. No fraction representing an aggregate of both subunits is obtained, as in previously reported methods $(3,7)$. Components $C$ and $D$ are now consistently isolated from $\alpha \mathrm{P}$ in a weight ratio close to $3: 1$. The amino acid compositions of $\alpha \mathrm{P}$, fraction II, and fraction III (Table I), when expressed as grams of each residue $/ 100,000 \mathrm{~g}$ of protein, are similarly consistent with the presence of these two subunits in $\alpha \mathrm{P}$ in a weight ratio of $3: 1$. If both peptides have a molecular 
weight close to $15,000(7,8)$, then the molar ratio of $\mathrm{C}$ and $\mathrm{D}$ in $\alpha \mathrm{P}$ will also be $3: 1$.

Perhaps each $\alpha \mathrm{LP}$ particle likewise contains peptides $C$ and $D$ in a molar ratio of $3: 1$, together with various lipids. Alternatively $\alpha \mathrm{LP}$ may not be homogeneous with regard to peptide composition. As an extreme example, human serum might contain two types of $\alpha \mathrm{LP}$ (with closely similar electrophoretic mobilities and densities), one based on peptide $C$ and the other on $D$. Determination of the ratios of $\mathrm{C}$ to $\mathrm{D}$ in appropriate subfractions of $\alpha \mathrm{LP}$ will clarify this problem.

\section{ACKNOWLEDGMENTS}

This work was supported by U. S. Public Health Service Grants AM 13129, AM 13122, and FR-39, and by a grant from the Georgia Heart Association.

\section{REFERENCES}

1. Scanu, A., L. A. Lewis, and I. H. Page. 1958. Studies on the antigenicity of $\beta$ - and $\alpha_{1}$-lipoproteins of human serum. J. Exp. Med. 108: 185.

2. Rodbell, M., and D. S. Fredrickson. 1959. The nature of the proteins associated with dog and human chylomicrons. J. Biol. Chem. 234: 562

3. Rudman, D., L. A. Garcia, L. L. Abell, and S. Akgun. 1968. Observations on the protein components of human plasma high- and low-density lipoproteins. Biochemistry. 7: 3136 .

4. Scanu, A. 1966. Forms of human serum high density lipoprotein protein. J. Lipid Res. 7: 295.

5. Shore, V., and B. Shore. 1967. Some physical and chemical studies on the protein moiety of a high-density
$(1.126-1.195 \mathrm{~g} / \mathrm{ml})$ lipoprotein fraction of human serum. Biochemistry. 6: 1962.

6. Sodhi, H. S., and R. G. Gould. 1967. Combination of delipidized high density lipoprotein with lipids. J. Biol. Chem. 242: 1205.

7. Shore, B., and V. Shore. 1968. Heterogeneity in protein subunits of human serum high-density lipoproteins. Biochemistry. $7: 2773$

8. Shore, V., and B. Shore. 1968. Some physical and chemical studies on two polypeptide components of highdensity lipoproteins of human serum. Biochemistry. 7: 3396.

9. Zahler, P. H., and D. F. Wallach. 1967. Isolation of lipid-free plasma membrane proteins by gel-filtration on Sephadex LH-20 using 2-chloroethanol-water as solvent. Biochim. Biophys. Acta. 135: 371.

10. Hirs, C. H. W., S. Moore, and W. H. Stein. 1956. Peptides obtained by tryptic hydrolysis of performic acidoxidized ribonuclease. J. Biol. Chem. 219: 623 .

11. Rosenthal, H. L., M. L. Pfluke, and J. Callerami. 1959 The colorimetric estimation of serum fatty esters. Clin. Chim. Acta. 4: 329.

12. Ornstein, L., and B. Davis. 1962. Disc electrophoresis. Preprinted by Distillation Products Industries, Rochester, N. Y.

13. Fiske, C. H., and Y. Subbarow. 1925. The colorimetric determination of phosphorus. J. Biol. Chem. 66: 375.

14. Abell, L. L., B. B. Levy, B. B. Brodie, and F. E. Kendall. 1952. A simplified method for the estimation of total cholesterol in serum and demonstration of its specificity. J. Biol. Chem. 195: 357.

15. Procedures Manual, Model $120 \mathrm{C}$ amino acid analyzer. 1966. Spinco Division of Beckman Instruments, Inc., Palo Alto, Calif.

16. Moore, S. 1963. On the determination of cystine as cysteic acid. J. Biol. Chem. 238: 235.

17. Spies, J. R., and D. C. Chambers. 1949. Chemical determination of tryptophan in proteins. Anal. Chem. 21: 1249. 